\title{
11. 機械工作用セラミックス
}

\section{1 研 削 砥 石}

\section{(1) 緒 言}

研削砥石の発達は金属, 機械工業にほとんど平行して 延びている. 金属の種類, 加工機械の高性能のものが多 く開発されているのに比較して, 必ずしも研石の性能が 全面的につい随できているとはいえない.

現在の砥石の型式すなわち切刃の役割をはたす砥粒， これを連結する結合剤, 機械的機能と関係の深い気孔， これら三者の型式の工具では加工用具としての限界にい つかは到達するととが予想できる．旧来の砥石の製法に 関してはすでにハンドブックその他に出ているが，新し い傾向としての碰石については文献照会が他のセラミッ クスに比べて少ない。

\section{（2）研削砥石の発展の傾向}

今日の兂石製造者，使用者の努力している方向はいか にして粗研削において速度，圧力を上昇させて研削効率 の上景と低コスト が得られるかに集 中されている。図 1,2 にその傾向を 示す之砥石圧力， 速度に比して工作 費，効率の上によ く現われている。

これらの要求を 満すためには碰粒 の改良問題があ り，また結合凨の 新種が必要とな る。

旧来の Vit 础 石については粗研 削用のような飛躍 的性能の要求はな

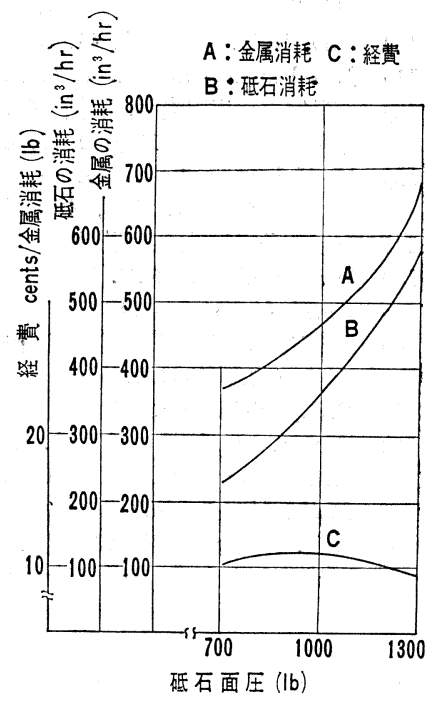

図-1ステンレス鋼スナッギングに おけるスラブ用砥石の圧力の 影響 $(12,000 \mathrm{ft} / \mathrm{min})$
いが，精密な工作における性能の向上および新しい成分 の被研削材すなわち超硬その他のための砥粒の改良，製 造に関連した研削理論に少しづつ発展の道が開かれつつ ある・てれらと別に人造ダイヤモンドが新用途，製造法 の改良に現われている.

\section{(3) 研削用砥粒の種類形式}

研削碰石の直接的な研削作用は碰粒が働くが，きわめ て単時間 $10^{-5} \sim 10^{-6}$ 秒の瞬間に切削仕事をするための
被研削材の成分, 結晶 構造なぞ（ねばさ，脆 さを変えた）の特性に より研粒の役割をいく つかの種類にわけなけ ればならなくなる。し かしきわめて短時間に 行なわれるから，その 作用を解析的に精密に 区別して研粒の性質を 説明するまでにはまだ 至っていない。したが って研削加工界では靯 性（砥粒の破壞性に対 する抵抗の程度を指 す)の多少で総括的説 明用語としている。乙 の分類の仕方で米国の

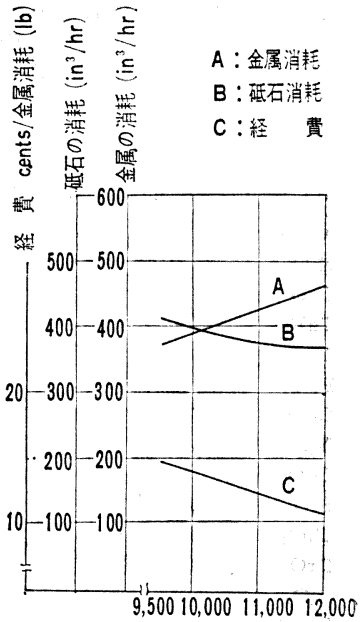

研石速度 $(\mathrm{ft} / \mathrm{min})$

図-2 ステンレススナッギング におけるスラブ砥石の速 度の影響 ( $1,000 \mathrm{lbs}$ 压)
砥石に用いられている砥粒の実用上の形式を示すと表-1 のようになる。

（3-1） アルミナ質砥粒 1901 年米国 Norton Co. はアルミナ質研粒 $\mathrm{A}$ を発売し, 後に続々と新種 $38 \mathrm{~A}$ (1910)， $57 \mathrm{~A}$ (1940)， $32 \mathrm{~A}$ (1946) (単一結晶哐粒), $44 \mathrm{~A}$ (1956) 近頃では $75 \mathrm{~A}$ まで発表してきている. てれら新種はいずれもわが国より先へ先へと発表してい るもので，なぜてのように研究が進み実用化が早いかは われわれとしては，実に重要な問題であるが別に研究の 論文にゆずり，それぞれの特徴について説明する。

$44 \mathrm{~A}$ (Heavy duty 強鞓性) の新種は発表に先がけて 2 年前 (1954) 頃から全研究室をあげて実験計画が行な われ，さらに自社の取引工場で 1,100 回の実験の成績が 含まれている.

てのような大きな組織ではかってわが国で行なわれて いないが，他山の石とするところがある.(その後わが国 でも小規模ながら行なわれるようになった４4 A は細か い肌目をしており，非常に大きな Strength と Toughness が特徴である.したがって用途は $38 \mathrm{~A} や 32 \mathrm{~A}$ の ような切刃の出やすい（発刃しやすい）平面研削や工具 研削の用途には向かない，よって，靶性のある Heavy duty 用として Vitrified 結合剮では BE, G を用い，レ ジノイド結合剤では B 11 などが推奨されている．代表 的な研石の構成，用途は，

\section{A 54 LVBE 円筒研削用}


表-1 砥石製造における砥粒の種別と適性

酸 化アルミニウム

炭 化 珪 素

\begin{tabular}{|c|c|c|c|c|c|c|c|c|c|c|c|c|}
\hline 製造 & $\begin{array}{l}\text { Heavy } \\
\text { Duty }\end{array}$ & Regular & $\begin{array}{l}\text { Semi- } \\
\text { Friable }\end{array}$ & $\begin{array}{l}\text { Friable } \\
\text { White }\end{array}$ & $\begin{array}{c}\text { Corun } \\
\text { dum } \\
\text { Natura }\end{array}$ & $\begin{array}{c}\text { Mixture } \\
\text { of } \\
\text { al) Al. Ox. }\end{array}$ & $\begin{array}{l}\text { Mixture } \\
\text { of Al.Ox. } \\
\text { \& S.C. }\end{array}$ & $\begin{array}{c}\text { Heavy } \\
\text { Duty }\end{array}$ & $\begin{array}{l}\text { Regu- } \\
\text { lar }\end{array}$ & $\begin{array}{l}\text { Semi- } \\
\text { Friable }\end{array}$ & e $\begin{array}{c}\text { Friable } \\
\text { Green }\end{array}$ & $\begin{array}{l}\text { Mix } \\
\text { of } \\
\text { S.C. }\end{array}$ \\
\hline $\mathrm{AC}$ me & $\mathrm{RA}, \mathrm{DA}$ & $\mathbf{A}, \mathbf{U} \mathbf{A}$ & FA & - & - & WA & $\begin{array}{l}\text { CA, C1A, } \\
\text { C2A, C3A, } \\
\text { C } 4 \mathrm{~A}\end{array}$ & - & C & - & - & - \\
\hline Allison Cambell & - & $\mathbf{A}$ & DA & WA & - & $\mathbf{X A}, \mathbf{V A}$ & - & - & C & - & GC & - \\
\hline American Emery & $\mathrm{RA}$ & A & $29 \mathrm{AA}, 2 \mathrm{~A} 7$ & $77 \mathrm{~A}, 11 \mathrm{~A}$ & - & MA & $\mathrm{CA}$ & $\mathrm{C}$ & $\mathrm{C}$ & F C & GC & $\mathrm{AC}$ \\
\hline Atlantic & - & $\mathbf{A}$ & - & - & - & - & - & - & C & - & GC & $\rightarrow$ \\
\hline Bay State & $\mathrm{HA}, \mathbf{R} \mathbf{A}$ & $\mathbf{A}$ & $3 \mathrm{~A}$ & $7 \mathrm{~A}, 8 \mathrm{~A}$ & $9 \mathrm{~A}$ & $8 \mathrm{~A} ; 2 \mathrm{~A}, \mathrm{SA}$ & $\mathrm{CA}, \mathrm{MA}$ & $7 \mathrm{C}$ & C & - & $1 \mathrm{C}$ & $3 \mathrm{C}$ \\
\hline Bullard & $3 \mathrm{~A}$ & A & F A & WA & - & $6 \mathrm{~A}$ & $\mathrm{CA}$ & - & C & F C & - & $6 \mathrm{C}$ \\
\hline Carborundum & WA & A, TA & $\mathrm{GA}, \mathrm{SA}$ & AA & - & $\begin{array}{c}\text { DA, FA, } \\
\text { HA }\end{array}$ & $\mathrm{C} 3 \mathrm{~A}, \mathrm{C} 4 \mathrm{~A}$ & WC, TC & $\mathrm{CI}$ & B C , S C & GC & $\mathrm{RC}$ \\
\hline Chicago & - & A51 & SA 52,54 & 53,55 & - & 50 & - & - & C49 & - & GC & - \\
\hline Cincinnati & $1 \mathrm{~A}$ & A & $2 \mathrm{~A}, 4 \mathrm{~A}$ & $9 \mathrm{~A}$ & $97 \mathrm{~A}$ & - & $\begin{array}{c}\mathrm{CA}, \mathrm{C2A} \\
\mathrm{C} 4 \mathrm{~A}\end{array}$ & - & $6 \mathrm{C}$ & - & $5 \mathrm{C}$ & $7 \mathrm{C}$ \\
\hline Colonial & EDA & A & TA, NA & $20 \mathrm{~A}$ & - & $\begin{array}{l}\text { 5A,10A, } \\
15 \mathrm{~A}, 5 \mathrm{TA}, \\
10 \mathrm{TA}, \\
15 \mathrm{TA}\end{array}$ & $\begin{array}{l}\text { 5TAC, } \\
\text { 10TAC, } \\
5 \text { CTA, } \\
\text { 10CTA }\end{array}$ & C & $\mathrm{C}$ & - & GC & - \\
\hline Cortland & SA & $\mathbf{A}$ & F A, B A & WA & - & $\mathrm{GA}, \mathrm{EA}, \mathrm{DA}$ & $\mathrm{CA}$ & S C & C & - & GC & $\mathrm{MC}$ \\
\hline de Sanno & A & $\mathbf{A}, \mathbf{A T}$ & $7 \mathrm{~A}, 7 \mathrm{AT}$ & $\begin{array}{l}9 \mathbf{A}, 10 \mathrm{~A}, \\
\quad \mathbf{R G}\end{array}$ & $-\mathrm{I}$ & $\begin{array}{c}\text { 97A, J A, } \\
\mathbf{K A}, \mathbf{K T A}, \mathbf{S} \mathbf{A}\end{array}$ & $\begin{array}{l}\text { CA, DA, } \\
\text { A } \mathrm{FA}, \mathrm{GA}\end{array}$ & - & C & - & GC & - \\
\hline Eagle & $\mathrm{DA}$ & $\mathbf{A}$ & TA & $66 \mathrm{~A}, 62 \mathrm{~A}$ & - & $22 \mathrm{~A}, 33 \mathbf{A}$ & 44 & - & $88 \mathrm{C}$ & - & $\mathrm{GC}$ & - \\
\hline Electro & $10 \mathrm{~A}, \mathrm{RA}$ & $\mathbf{A}, \mathbf{E A}$ & $\begin{array}{c}5 \mathbf{A}, 11 \mathbf{A} \\
F \mathbf{A}\end{array}$ & $1 \mathbf{A}$ & - & $\begin{array}{c}2 \mathrm{~A}, 3 \mathrm{~A}, 4 \mathrm{~A} \\
6 \mathrm{~A}, 8 \mathrm{~A}, 9 \mathrm{~A} \\
12 \mathrm{~A}\end{array}$ & $\begin{array}{l}\text { CA,DA, } \\
7 \mathbf{A}, \mathbf{B A}\end{array}$ & - & C & - & GC & $\mathrm{HC}$ \\
\hline Fuller & 一 & A & $\mathbf{F A}, \mathbf{J} \mathbf{A}$ & $\mathbf{B A}$ & $\mathrm{D}$ & HA & CA & - & $\mathrm{C}$ & - & G C & $\mathrm{RC}$ \\
\hline Gardner & $-A$ & $\mathrm{~A} 84 \mathrm{~A}, 87 \mathrm{~A}$ & $82 \mathrm{~A}$ & $80 \mathrm{~A}$ & - & $\begin{array}{c}81 \mathrm{~A}, 83 \mathrm{~A}, 85 \mathrm{~A} \\
86 \mathrm{~A}, 88 \mathrm{~A}\end{array}$ & - & - & C & - & GC & $\mathrm{AC}$ \\
\hline General Grinding & $3 \mathrm{~A}, \mathrm{~T} \Lambda$ & $\mathbf{A}$ & $2 \mathrm{~A}, 4 \mathrm{~A}$ & $10 \mathrm{~A}$ & 3 & $\mathbf{H A}, \mathbf{K A}$ & RA, EA & - & $\mathrm{C}$ & - & $7 \mathrm{C}$ & $\mathrm{BC}$ \\
\hline Hampden & $\begin{array}{c}\text { TA, GA } \\
3 \mathrm{~A}\end{array}$ & FA & EA & WA & C & - & $\mathbf{C A}$ & C & - & - & GC & - \\
\hline Jowitt\& Rodgers & - & G & B & $\mathbf{W}$ & - & - & - & - & $\mathbf{x}$ & 一 & GC & - \\
\hline Keystone & $Z \mathrm{~A}$ & $\mathbf{A}$ & $\mathbf{F A}, \mathbf{J} \mathbf{A}$ & WA & GA & $\mathbf{L} \mathbf{A}, \mathbf{H A}, \mathbf{R} \mathbf{A}$ & - & - & C & - & GC & - \\
\hline Macklin & - & $\mathbf{A}$ & 29,27 & $48^{3}$ & 31 & 18 & $\mathrm{AC}$ & - & C & 一 & GC & $\mathrm{HC}$ \\
\hline Manhattan & L F & $F$ & w & - & - & FW & FS \& a & - & 5 & - & G & G S \\
\hline Mid West & $5 \mathrm{~A}$ & $1 \mathrm{~A}, \mathbf{A}$ & $8 \mathbf{A}, 11 \mathbf{A}$ & $2 \mathrm{~A}$ & 6 & $4 \mathrm{~A}, \mathrm{~S} 11 \mathrm{~A}$ & $\mathrm{AC}$ & $\mathrm{C}$ & $3 \mathrm{C}$ & - & $7 \mathrm{C}$ & $3 \mathrm{C}$ \\
\hline National & - & A & $\mathbf{P A}, \mathbf{H A}, \mathbf{B} \mathbf{A}$ & $\mathbf{S A}$ & - & MA & $\mathbf{C A}$ & - & C & - & GC & $\mathrm{AC}$ \\
\hline Norton & $44 \mathrm{~A}, 75 \mathrm{~A}$ & $\mathbf{A}$ & $57 \mathrm{~A}, 23 \mathrm{~A}$ & $32 \mathrm{~A}, 38 \mathrm{~A}$ & - & $19 \mathrm{~A}$ & $\begin{array}{l}\mathrm{AC}, \mathrm{A} 1 \mathrm{C}, \\
\mathrm{A} 2 \mathrm{C}, \mathrm{A} 3 \mathrm{C}\end{array}$ & - & $37 \mathrm{C}$ & - & $39 \mathrm{C}$ & - \\
\hline Pacific & 25 & A & 35 & 50,47 & - & 40,45 & 70 & - & 75 & - & 80 & - \\
\hline Penisular & $4 \mathrm{~A}$ & A & $\mathbf{F A}, \mathbf{B A}$ & $\mathbf{3 A}$ & NA & WA, RA & $\mathrm{CA}$ & - & C & - & GC & $\mathrm{GC} / \mathrm{C}$ \\
\hline Precision & MA & $\mathbf{A}, \mathbf{T A}$ & $\begin{array}{l}\text { FA, FAA } \\
\text { FRA, GA }\end{array}$ & $\begin{array}{l}\text { AA } \\
\text { RAA }\end{array}$ & NA & - & CA, FCA & - & C & BC & $\mathrm{DC}$ & - \\
\hline Red Hill & - & A & $\mathbf{F A}$ & WA & - & $\mathbf{H A}$ & $\mathrm{AC}$ & - & $\mathrm{C}$ & - & GC & - \\
\hline Robertson & SA & $\mathbf{F A}, \mathbf{H A}$ & RA, LA & WA & - & - & BA & C & J C & 一 & GC & - \\
\hline Simonds Abrasive & DA & A & $\mathbf{J} \mathbf{A}, \mathbf{X} \mathbf{A}$ & WA, SA & - & NA & BA & $\mathrm{SC}$ & C & - & GC & - \\
\hline Simonds Worden & $4 \mathrm{~A}$ & A & $5 \mathbf{A}, 7 \mathbf{A}$ & $8 \mathrm{~A}$ & - & $6 \mathbf{A}, 9 \mathbf{A}$ & $\mathrm{AC}$ & - & $\mathrm{C}$ & - & GC & $\mathrm{CGC}$ \\
\hline Sterling & HA & A & $\mathbf{K A}, \mathbf{P A}$ & WA & $\mathbf{X A}$ & $Z \mathbf{A}, \mathbf{E A}$ & J A & $\mathrm{C}$ & $\mathrm{C}$ & C & GC. & SC \\
\hline Titan & AL. & A L & $\mathbf{F A}, \mathbf{B A}$ & WA & $-n$ & $\begin{array}{c}\text { WFA, WBA, } \\
\text { B F A }\end{array}$ & $\mathrm{AC}$ & C & C & - & $\mathrm{GC}$ & C \\
\hline U.S. Rubber & $\mathrm{DA}, \mathrm{KA}$ & A & B A & WA & - & $\begin{array}{c}\text { A4A, B4A, } \\
\text { C4A,D4A, } \\
\text { W4A }\end{array}$ & $\begin{array}{c}\text { S4A, E4A, } \\
\text { F4A, } 81 \mathrm{~A}\end{array}$ & - & C & - & - & - \\
\hline Vitrified & - & A & $8 \mathbf{A}$ & $9 \mathbf{A}, 13 \mathrm{~A}$ & - & $6 \mathbf{A}, 8 \mathbf{A}$ & $7 \mathrm{~A}$ & - & C & - & $\mathrm{GC}$ & $\mathrm{HC}$ \\
\hline Walthan & $\mathbf{A}$ & $\mathbf{A}$ & $68 \mathrm{~A}$ & $\begin{array}{l}\text { WA, } 11 \mathrm{~A} \\
\quad 12 \mathrm{~A}\end{array}$ & - & $\begin{array}{c}14 \mathrm{~A}, 34 \mathrm{~A}, \\
\mathrm{SA}\end{array}$ & $\mathrm{CA}, 16 \mathrm{~A}$ & C & C & - & G C & $\mathrm{MC}$ \\
\hline estfield & - & $\mathbf{A}$ & $\mathrm{FA}, 77 \mathrm{~A}$ & $75 \mathrm{~A}$ & - & $\begin{array}{c}72 \mathrm{~A}, 73 \mathrm{~A}, \\
74 \mathrm{~A}\end{array}$ & $\mathrm{CA}, 76 \mathrm{~A}$ & - & $\mathrm{C}$ & - & $\mathrm{GC}$ & - \\
\hline
\end{tabular}

44 A 46 MVG 鋸刃研磨用

44 A 60 LVG 一般センターレス用

$44 \mathrm{~A} 14$ QB 11 高速 Swing-Frame 用

その後 $75 \mathrm{~A}$ (表-1 中第一行強靱性) が出され，わが 国でも相当な反響を呼んだ. その原因は従来の研粒の性 質の型を破った性質があり， $\mathrm{SiO}_{2}$ を $3.0 \%$ 以上も含 みかつ $\mathrm{Fe}_{2} \mathrm{O}_{3}$ を 5 6\%, $\mathrm{TiO}_{2}$ を〜3\%〜 示したから である:一般的に従来のアルミナ質砥粒はけい酸の少な いことが普通で, かつ $\mathrm{Fe}_{2} \mathrm{O}_{3}$ も余り多いととは歓迎さ れないのが常識であって，少しての新種について述べ
る. 製造側の説明では,

$\begin{array}{lr}\mathrm{SiO}_{2} & 3.94 \\ \mathrm{Fe}_{2} \mathrm{O}_{3} & 6.14 \\ \mathrm{TiO}_{2} & 3.05 \\ \mathrm{Al}_{2} \mathrm{O}_{3} & 86.87\end{array}$

また比重が軽く衝撃に強いととも一般の溶融したアルミ ナ重研削用碰粒と異なり，3.95 に対して 3.70 の軽さも 大きな特徵といえよう．高圧縮破壊性が一般の 3 倍とも いわれる。

この種の碰粒については Norton Co, Exolon Co, 
Carborundum $\mathrm{Co}$,で寻競って研究し特許権に関連する 内容まで発展したようであるだけに問題は大きな照点に さらされた。

$75 \mathrm{~A}$ 䃌粒の特徵は成分にもあるが，製造方式にもあ る.X 線や顕微鏡で検査した結果では不純物と見なさ れていた珪酸, 鉄, チタンの多量な含有物は多くは製造 中に発生したムライト結晶あるいは生成ガラス組織のう ちに含まれるらしい，ての製造技術は秘密が含まれてい るが，シンターした Bauxite あるいはシンターしたア ルミナで. アーク炉によらなくとも高温炡でもでき Polycrystalline であることが成分，組織とともに高勒性 を発揮する所謂といわれる。

用途としてはステンレス，工具鋼が主でレジノィド砥 石として使用し金属加工の膨大な最近の使用量に対応で きるものである。

（3-2） ジルコニウム系の新砥粒 近年チタニウム， ジルコニウム，新種ステンレス鋼，新超硬合金その他新 しい金属種がぞくぞく現われてくるようになったので， 表-1 に示すようなアルミナ系，炭化珪素系，それらの 混合系ではどうしても研削不能の状態におちいりつつあ る・オーステナイト型ステンレス鋼, チタニウム，ジル コニウムのバリ取りはそのうちでの当面の困った問題で ある。

近頃 $\mathrm{TAM}$ と称して $\mathrm{ZrO}_{2}+\mathrm{TiO}_{2}(85 / 15)$ の新しい碰 粒がての問題の対策として優れているてとが認められつ つある. 次の表に炭化珪素, 溶融アルミナ, TAM，溶 融ジルコニアの硬さ，䩓性（鋼球ボールミル試験）比重 を示す,

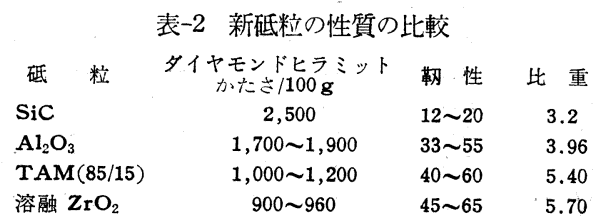

またバリ取りの研削では，

表-3 バリ取り研削試験結果

䃨 粒 1 時間当り研削量 (1bs)/1 時間当り磨耗量 $\left(\mathrm{in}^{3}\right)$ 溶融アルミナ

TAM 85/15

22.46

93.42

ての結果によれば $\mathrm{ZrO}_{2}-\mathrm{TiO}_{2}$ 碰粒は溶融アルミナ粒 に比べて研削能率が約 $400 \%$ も増大する.しかし大切な ことはこれら新砥粒が発見される動機となるべき理論や 研究経過であるがほとんど知られていない。

（3-3） ダイヤモンド砥粒ダイヤモンドは問題とな っているが，ての頃では碰石の製造として取扱いダイヤ モンドの合成や理論は省いた：

ダイヤモンドのかたさ：ダイヤモンドの研削効果を判 断するときいつも問題となるのはかたさである。モース のかたさや一般のかたさの測定でもダイヤモンドが基準 となっているのでなおさら困難性が伴う．
しかし Tavor（1954）はかたさには異方性のあること を見出したが重要な問題である。

一般的にかたさを求める方法としてはいくつかがある が，機械工作の工具の切刃として用いた磨耗抵抗または 研削，ポリシングに対する抵抗のいずれかに特徵を見出 すととに注目がそそがれている．工具としてダィヤモ ンドを使用したときの磨耗比は Whittaker, Slawson (1946) および Winchell (1956) らが始めて測定した。 ダイスにダイヤモンドを用いたときの磨耗比は Peters， Emerson, Neffien, Harris および Cooter (1947) らが 行ない最近 Schultnik (1961) によって全体的に報じて いる。

その他磨耗の仕方，その測定によるかたさの比較研究 は相当数に上っているが，ほとんど何の方法も違った結 果が出やすい，しかしひとつの点だけは共通している. それはダイヤモンドはある方向ではそれ以外の方向にお けるよりも大きな磨耗抵抗をもつことである。

しかしてれらの測定にもかかわらず正確な結果はえら れず，研削やポリシングの場合，ダイヤモンドの磨耗が 機械的なピッチングによって起こるのか，黒鉛になると いう熱変態によって発生するのかあいまいな点が残され ている.

\section{(4) 研削砥石}

研削砥石の具体的な一般製法については文献が少ない が，ハンドブックその他に出ているので，主としてレジ ノィド砥石，ダイヤモンド砥石のような新しいものにつ いて述べる。

（4-1）レジノイド砥石 結合剤としては強度と価格 の点でいぜんとしてフェノール樹脂系のものが多い．し かし製造上の技術としてはフェノール製造業側に依存す る点は䃌石製造業の難点として変りなく，種々の新型樹 脂も出てきているが，砥石製造の立場より見ればフィラ 一も相当に改良手段として大きな問題である。しかし困 ることはフィラーについての理論的根拠が比較的乏しい ものもあることである．とれらを上げて見ると，

1. 真珠岩, 浮石, 溶融粘土球などは研石の内部に気 孔を作るのに用いられる，砥石の結合度を低下させ軟ら かくして高速回転に使用するのに適する。

2. グラスファイバー，アスベストのような繊維は強 さと高速化の安全性を増す。

3. 添加剤の一種に樹脂の反応に影響を与光て性質を 変化させるものもある．たとえば樹脂の重合の場合アル カリ触媒として石灰のようなフィラーも塩基性の活性化 により重合をすすめる．他偣酸鈆，コロイド状水酸化 物もフェノール酸類に反応して有効といわれる.

4. 石灰, 硫酸カルシウム, 活性化マグネシア, 活性 化アルミナのようなフィラーは樹脂の縮合, 重合におい て水に反応する．てれらにより結台剤の質量の大小が元 
られ，比重の調整ができる.

5. フィラーは物理的に樹脂の結台力や吸着力を変え られ，䃌石の研削における作動や効率を改めることがで るる・樹脂とフィラーの比は大幅に可変で, 安全性やス ピードと調整して砥石の限界の加減ができる.

6.フィラーは研削面で滑剤の働きをするようにしな ければならないので, 塩類や共融体物質を用いて研削面 温度より低くするてともある。

7.フィラーは研削面温度で一役を受持っている。す なわちフィラー一低粒, フィラー一結合剤, フィラー一 金属加工面で反応しやすい.したがってフィラーとして

\begin{tabular}{|c|c|c|}
\hline 表-4 & \multicolumn{2}{|c|}{ 砥石用フィラーについての特許（米国特許） } \\
\hline 許番号 & 日付 & フィラ一組成 \\
\hline $\begin{array}{l}\text { Brit } \\
\quad 444,141\end{array}$ & $3 / 16 / 36$ & $\begin{array}{l}\text { フィラー組成ンエラック結合剤中へクリオライ } \\
\text { 卜を含む砋石 }\end{array}$ \\
\hline $1,576,122$ & $3 / 9 / 26$ & 焼石，湄 \\
\hline $1,984,423$ & $12 / 18 / 34$ & $\begin{array}{l}\text { 二酸化マンガン, クロム酸アンモニウム, 重ク } \\
\text { ロ公酸アンモニウム, 過マンガン酸加里, 過マ } \\
\text { ンカン酸ソータ }\end{array}$ \\
\hline $2,022,893$ & $12 / 3 / 35$ & 可溶弗化物, $\mathrm{CaF}_{2}$, クリオライト \\
\hline $2,033,668$ & $3 / 10 / 36$ & $\begin{array}{l}\text { 塩化力ルンウムを含さ塩化垔鉛えの他潮解性の } \\
\text { 塩を加した砥石 }\end{array}$ \\
\hline $2,083,719$ & $6 / 15 / 37$ & 酸 化 鉛 \\
\hline $2,110,630$ & $3 / 8 / 38$ & クリオライト \\
\hline $2,197,552$ & $4 / 16 / 40$ & セレニウム, テルリウムおよびその硫化物 \\
\hline $2,216,135$ & $10 / 1 / 40$ & $\begin{array}{l}\text { アルカリ，アルカリ士類塩化物およで炭酸塭 } \\
\text { 溶融点 } 700 \sim 1,200^{\circ} \mathrm{C}\end{array}$ \\
\hline $2,243,049$ & $5 / 20 / 41$ & $\begin{array}{l}\text { 酸性硫酸ソーダを含む硫酸, 橉酸の無水および } \\
\text { 塭類 }\end{array}$ \\
\hline $2,249,278$ & $7 / 15 / 41$ & $\begin{array}{l}\text { 無機脱水剂酸化カルンウム, 硫酸カルンウム, } \\
\text { 活性化アルミ゙ナ }\end{array}$ \\
\hline $2,258,774$ & $10 / 14 / 41$ & 粉体鉛, 錫, 銅および鉛, 錫, 銅の低融点合金 \\
\hline $2 ; 294,239$ & $8 / 25 / 42$ & 活性化マクネンア，婽焼菱苦土鉱 \\
\hline $2,308,981$ & $1 / 19 / 43$ & 硫酸鉄 \\
\hline $2,308,982$ & $1 / 19 / 43$ & 硫酸カルンウム加里, 硫酸加里 \\
\hline $2,308,983$ & $1 / 19 / 43$ & 弗哪化アルカリ金属 \\
\hline $2,325,180$ & $7 / 27 / 43$ & 鉄, マンガン, モリブデンの重金属硫化物 \\
\hline $2,371,700$ & $3 / 30 / 45$ & $\begin{array}{l}\text { チタニウム, バナシウム, クロム, マンガン, } \\
\text { 鉄, コバルド, ニッケル類の金属の酸化物との } \\
\text { 樹脂の反応 }\end{array}$ \\
\hline $2,371,915$ & $3 / 20 / 45$ & 膠質水和酸化金属を混えた樹脂 \\
\hline $2,408,319$ & $9 / 24 / 46$ & 硫化鉄と硼弗化加里共に存在 \\
\hline $2,638,413$ & $5 / 12 / 53$ & ハロケンン化鉛, 硫酸鉛 \\
\hline $2,729,553$ & $1 / 3 / 56$ & $\begin{array}{l}\text { 石灰またはマケネシアを加えたカルシウム， マ } \\
\text { クシウム、バリウムの弗化物 }\end{array}$ \\
\hline $2,734,812$ & $2 / 14 / 56$ & $\begin{array}{c}\text { 気孔または空胴粒, 空胴がラス, 膨脹パーラィ } \\
\text { ト }\end{array}$ \\
\hline $2,745,729$ & $5 / 15 / 56$ & 被膜硫黄粒 \\
\hline $2,780,534$ & $2 / 5 / 57$ & 退化アンチモン \\
\hline $2,806,772$ & $9 / 17 / 57$ & 空胴鹿壁セラミック球 \\
\hline $2,811,430$ & $11 / 29 / 57$ & $\begin{array}{l}\text { 硫酸, 塭類, 臭素酸のアルカリ金属塩と硫化重 } \\
\text { 鉛 }\end{array}$ \\
\hline $2,874,034$ & $2 / 17 / 59$ & 膨脹雲母矿物, 膨脹蛭石 \\
\hline $2,939,777$ & $6 / 7 / 60$ & 硫酸, 塩酸, 奥素酸のアルカリ金属塩と硫化鉛 \\
\hline 940,841 & $6 / 14 / 60$ & $\begin{array}{l}\text { 硫酸, 塩酸, 臭素酸のアルカリ金属塩と硫化ア } \\
\text { シチモン }\end{array}$ \\
\hline $2,940,842$ & $6 / 14 / 60$ & $\begin{array}{l}\text { 鉄, マンガン, アルミニウム, クロム, ニッケ } \\
\text { ル, 公ナヴム, タングステン, ジルニウム } \\
\text { と珪素合金 }\end{array}$ \\
\hline $2,949,351$ & $8 / 16 / 60$ & クリオライト, 塩化アンモニウム, 鉄 \\
\hline $2,952,529$ & $9 / 13 / 60$ & クリオライトと塩化アンモニウム \\
\hline （注）ク & オライト & 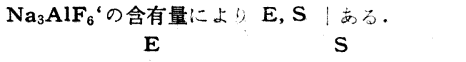 \\
\hline & $\mathbf{a}_{3} \mathrm{AlF}_{6}$ & 98.70 \\
\hline & $\mathbf{e}_{2} \mathrm{O}_{3}$ & 0.04 \\
\hline & $\mathrm{iO}_{2}$ & 0.70 \\
\hline & ulfide & 0.05 \\
\hline & の弗化物 & 0.66 \\
\hline 湿 & 分 & 0.05 \\
\hline & & 0.50 \\
\hline
\end{tabular}

$1,200^{\circ} \mathrm{C}$ 程度以上の溶融点のものは不適当といえる。 の他熱伝導率, 熱膨脹を変えさせる性質を応用して調整 飞使う。

上上の条件にかなうものを探すとかなりの数にのぼる が, 非常に多数の研究が競って行なわれ，その成果から 次の表-4 のような特許が生まれている.

（4-2）ダイヤモンド砥石 最近わが国でも人造ダイ ヤモンドの生産に成功している製造会社が二, 三できて おり, 今後天然多ヤモンドと比へて市場をにぎわすて とであううが，その結晶の特徵および価格の相異によっ てそれぞれの用途，製造手段が分れるととが予想され る.

a. 一般的砥石製法: 製造住当って注意を要するとと が 2 つる.ダイヤモンドは高価であるからまずその砥 石の使用方式に合った限界の厚さ, 量にダイヤモンド粒 を固定するととおよびダイヤモンドの耐酸化性, 耐熱性 の弱さを避けるため還元気流中で高温処理するととであ る.

b. 低温結合 : 軟質金属の銅, 青銅, 軟鉄へ機械的に ダイヤモンドを圧入する方法が多くとられている。.ての 方法の欠点は細かい粒度であると $(0.0067 \mathrm{~mm})$ 耐久力 が失われることで $0.1 \mathrm{~mm}$ 以上を用い石油, 水などの潤 かつ剤を必要とする.

c. 高温結合 : 軟質金属を用いると脱粒の数が多くな る欠点があり, 高温処理するとダイヤモンドが損傷する のであらかじめ焼もどし軽合金を用いて低い温度で結合 させる.合金と比重を接近させ（ダイヤモンド比重： 3.00 3.53) るごとも考えられているが，一般に低温度 で強い金属の硬いものが得られる.

d. 鍍金結合 : 電気鍍金をダイヤモンドの表面にほど こして金属膜を形成するやり方である.

ての方法は比較的小形砥石に多く用いられるが, 粒の 接触位置, 形状等の調整が必要で台座金属に固く接着さ せるために二ッケルやクロームその他が使用される、粒 子を並ばせるのに容易なとととダイヤモンドを損傷させ ないことが特徴で割合に安価に製造できる.

e. 粉体金属結合 : 粉末冶金学の発達に負うところが 多い。すなわち異種金属でも粉体焼結のできることで, 研磨，切断その他の研石ができる。たとえば Fe 1\%, Mo 26\%, Cu 27\%, Co 46\% とダイヤモンド粒の混合 物を加圧しながら烧結（ドィツ特許 583630）する法, ダイヤモンド粉, $\mathrm{Al}$ 粉 $40 \%, \mathrm{Si}$ 粉 $60 \%$ の混合物を 加熱焼結させるなど数多くのその他の方法などがあり， 粉体焼結技術の進んでくると同時に多数の金属種を異に した結合様式が行なわれつつある.

b. その他の結合 : 合成樹脂結合法, ビトリファイド 結合法は精密研削や超硬工具用としてかなり有望視され ており，特に合成樹脂法はフェノール系，エポキシある 


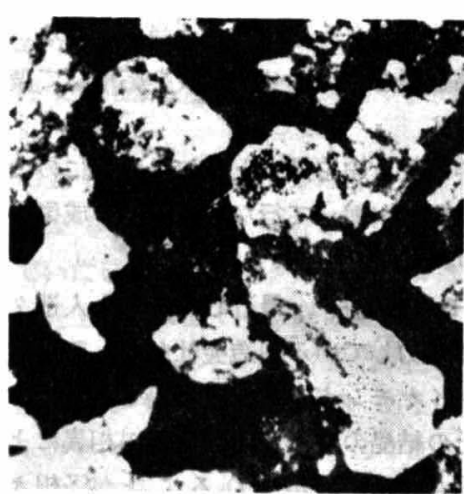

写真-1 人造タ゚イヤモンド RVG 砥粒

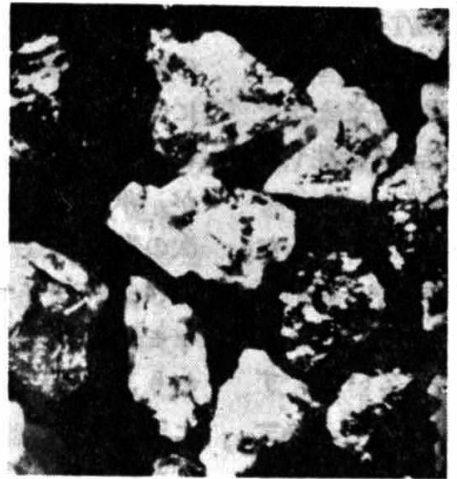

写真-2 人造ダイヤモンド MBG 砥粗

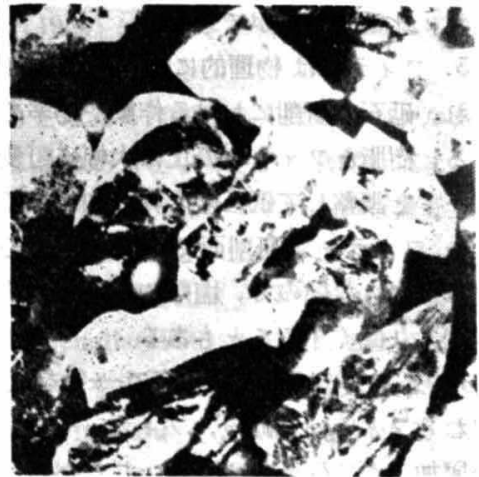

军真-3 天然ダイヤモ：ド砥种
いはその変成系その他の強力な結合剤が新らたに試みら れつつある。

人造ダイヤモンド砫石の効率 ダィヤモンド砫石の砥

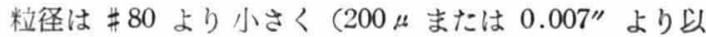
下) 単粒の强さを一つつ゚つ試験することは難しいが次の ようなととがわかった。

a) レジノイドピトリファイド砥石を用いて天然夕 イヤモンドと人造ダイヤモンドが武験された

b) 生の粒の粉末化試験では人造ダイヤモンドは天然 のものよりかなり弱い.

c）人造ダイヤモンドは比較的に天然のものより表面 が粗くギザギザがあってレジノイド，ビトリファイド結 合剤に刘し保持力に優れている.

しかし人造ダヤモンドは現在 RVG, MBG, MBS と 種類が分れているが，中でも MBS 潘新しく幾何学 的な面でよく用まれた形状をしている。

ダィヤモンド延石の効率はダイヤモンド粒の選び方, 並べ方, 結台方式で非常に違いまた研削条件によっても 影著な差があり，G. Pahlitzsh らの铎紏な研究がある。

ダィヤモント碰石の記号は炊のように示す

\section{100 - N 100 B $1 / 8$}

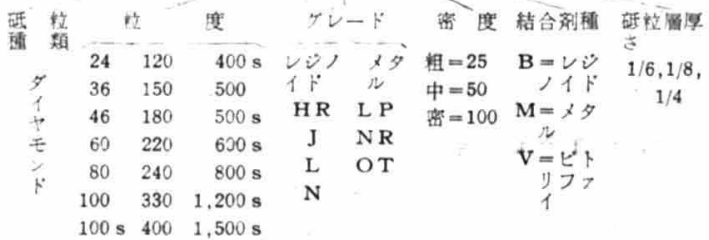

人造ダイヤモンドは米国の $\mathrm{GE}$ 社で始めて製造に成 功したのであるが. 最初に試験されたのはレジノド砥 石で好成績をおさめたといわれる。後に金属結合剂で使 用汇耐える强靬な研粒 MBG ができるようになり，切 断用も完成し, レジノイド,ピトリファイド用は RVG の記号を用いるようになった写真-1,2,3.いずれにして るダィヤモンド碰石は, 合成ダイモンドが䃌粒として 切刃の出やすいこと（破砕性に関連）之結合剤に保持さ れやすい特別の表面を持っていることが，天然砥石より
優れた原因であるらしいと認めら机ているようである。

（名古屋工業技術試験所 伊藤 幸人）

\section{2 研 磨 布 紙}

研磨布紙は製造方法の進步発展により大形 (広幅) 製 品ができて広い面樻の研削研整が迅速にできるため，研 削砥石の分野を增々広く侵蝕しつつある研磨工具であ る. その特徽は 1) 柔㜞出基材面に碈粓か強固に固着 していて広い面積を強力な粗研削が能率上くでるる，2) 㓮性, 弾性ある研削研磨加工で芯ふれのない加工が未熟 練者でもできる，3）曲面，平面とう均一平滑坛研箬が でさるなどである

研磨工具としての目的に適応するように多種類の研㽜 布紙があるが，日本工業規格では次の種類に大別してい

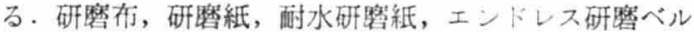
ト, 研䄷ジスク,そのほか研整布紙に類するエメリーフ イレットがある. それらの製造量”は月産的 38,000 連 (約 3 億円) でおよその内訳は耐水研整紙 $39 \%$ 。研穼紙 $31 \%$, 研磨布 $27 \%$, その他 $39 \%$ である。

研磨布紙之研削砥石の表示法の比輘を次に示寸

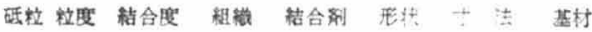

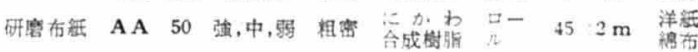

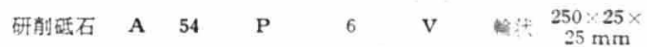

(1) 原 材 料

研削材……研磨布紙は研削砥石に比・碈杜ひ过度分布 が工作物の研磨面粗度を左右する因子が大き；，特に微

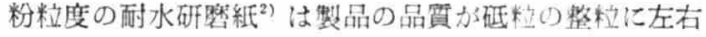
されるから精密な整精が必要である。整杜䂠粒サイ ズ, 形状（㷉平，針，塊状など）の選別てある。双晶 体，板状結晶の低粒は固着力研整力汃边る。

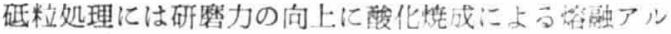

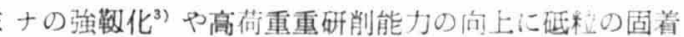
を旗力化させる烙融アルミナにセラミッんて材料を付着 㕞焼し，薄いへマタイトなどの皮膜被覆扰よ接着力

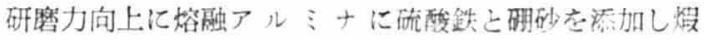

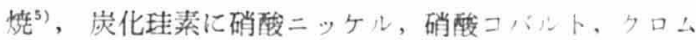


表-1 各種砥粒の硬さと磨耗率(6)

\begin{tabular}{|c|c|c|c|c|}
\hline & 砥 & $\begin{array}{l}\text { ヌープ } \\
\text { 硬·度 }\end{array}$ & 工 作物 & $\begin{array}{l}\text { 磨 } \\
\left(\mathrm{mm}^{3} / \mathrm{km} \mathrm{kg}\right)\end{array}$ \\
\hline 1) & 熔融アルミナ & 2,100 & 鋼 & $0.002 \sim 0.01$ \\
\hline 2) & 炭 化 珪 素 & 2,400 & $"$ & $0.01 \sim 0.05$ \\
\hline 3) & カ 一 木 & 1,360 & " & $0.045 \sim 0.066$ \\
\hline 4) & リ ン & 830 & " & $0.12 \sim 0.13$ \\
\hline 5) & $I x$ & 1,400 & $"$ & $0.055 \sim 0.075$ \\
\hline 6) & $\ddot{*} ル コ=P$ & $1,160^{\circ}$ & $"$ & $0.01 \sim 0.085$ \\
\hline 7) & ボ ン（結晶） & 2,900 & " & $0.06 \sim 0.105$ \\
\hline 8) & 炭化タングステン. & 1,880 & $"$ & $0.017 \sim 0.088$ \\
\hline 9) & タイヤモンド & 7,000 & $"$ & $0.0010 \sim 0.002$ \\
\hline 10) & 宸化チタ二ウム & 2,470 & " & 0.1 \\
\hline 11) & 崖化ジルコニウム & 2,100 & $"$ & 0.1 \\
\hline 12) & 硼化アルミニウム & 3,500 & $"$ & 0.12 \\
\hline 13) & 宸 & 2,750 & " & $0.08 \sim 0.14$ \\
\hline 14) & 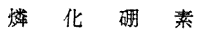 & - & $"$ & $0.14 \sim 0.18$ \\
\hline 15) & 砽化ジルコニウム & - & " & $0.04 \sim 0.08$ \\
\hline 16) & 硼化チタ二ウム & - & $"$ & $0.02 \sim 0.05$ \\
\hline 17) & 熔融アルミナ & 2,100 & 社な゙2鋳鉄 & $0.0017 \sim 0.0039$ \\
\hline 18) & 化 珪 素 & 2,480 & $"$ & 0.0006 \\
\hline 19) & ボ ン（結晶） & 2,900 & $"$ & 0.26 \\
\hline 20) & タイヤモンド & 7,000 & $"$ & 0.00013 \\
\hline
\end{tabular}

酸を添加煆燁らなどがある。

砥粒の硬さと磨耗は表-1に示す。

接着剤……基材処理, 研粒固着, 上引用により, 研磨 布紙の種類と使用条件（重研削，軽研磨，湿，乾式研磨 など）により接着剤の種類は多い，一般的で最も多量に 使用されるニカワは耐水性なく, 耐湿, 而熱性に乏しい が安価で柔軟性, 作業性良く, 接着力大きく耐油性大で 研磨冷却剂に灯油軽油油脂を用いる湿式研磨には使用で きるなどの利点がある.

フェノール系ユリヤメラミン系樹脂は接着力大きく最 近多く使用されるようになったが，柔軟性が乏しく高価 なためニカワの使用量には遠く及ばない.ラテックス， 油性ワニス,アルキド樹脂ワニス, エポキシ系樹脂は耐 水性に優れているが，高価なため耐水研磨紙布のみに使 用されている。ニカワ，ラテックス，乳化樹脂の溶剤は 水であるがワニス，樹脂の溶㓮は高価で火災，毒性問題 などから製造設備まで複雑化する。

充填材……接着力の增強と基材布の目止めに接着剤に 充填材を混合する, 一般に使用されているのは珠藻土， 蛹石, カオリン, タルク, セリサイト, 炭酸カルシウ
ム, 紅柄などである.

基材……綿布，クラフト紙，和紙，バルカナイズドフ アイバなどで低粒の支持体となる。強度, 桑軟性, 剛 性, 重量などが研磨布紙の特性を左右する。物理的特性

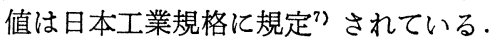

\section{（2）製 造 法}

研磨布紙の製造法8)を具体的に述べたものは少ないが 工程概略のを図-1 に示す.

基材処理……原綿布を湯通し, 目止め, カレンダー処 理して布面の平滑性，防伸性，接着性を向上させでロー ル巻きする. 目止め用に研磨布はビニール系樹脂，二カ ワなど，耐水研磨布紙はラテックス，油性また法アルキ ド系樹脂ワニスなどが用いられる.

接着剤塗布と低粒叙布……温度, 湿度を調整した塗布 室内で碰粒サイズに従った所定濃度，粘度の接着剤を口 ールコーター，フローコーターなどで塗布量を調整塗布 したのちにナイフドクター,ロールドクターなどで塗膜 厚を均一にし，接着剤鈢膜の粘着性を調整しつつ砥粒を ふきつけ，ふりがけ，静電などの方法で塗装し，加熱乾 燥で接着剤を硬化させ砥粒を固着する。

上引塗布……䃌粒間の空げきを接着剤で充填し，砥粒 の固着を強固にする. 接着骫の塗布はロールコーター, ふきつけなどによる：加熱乾燥硬化などは前工程と同様 である.一般に䃌粒固着用と上引用接着剤はニカワと二 カワ，樹脂と樹脂であるが品質向上とコス卜低减の目的 でニカワ之樹脂，樹脂と二カワの組合せのものが多くな ってきた。

ロール巻きにされだ間製品は検査選別されてて最終製 品の寸法形状に裁断や二次加工が行なわれる

接着剤濃度, 低粒叙布量を一般的な研磨布で一例を表 -2 飞示す。

\begin{tabular}{|c|c|c|c|c|c|c|c|c|}
\hline \multicolumn{9}{|c|}{ 表-2 } \\
\hline 研粒サイズ（番） & 40 & 60 & 80: & 100 & 120 & $150\}$ & 180 & 220 \\
\hline 差剂浀度 $\{$ ニカワ & 1 & 1 & 1 & 1 & 1 & 1 & 1 & 1 \\
\hline 浱仳 & 1 & 1.3 & 1.5 & 2 & 2 & 2.5 & 53 & 4 \\
\hline 熔融アルミナ AA $(\mathbf{g})$ & 65 & 60 & 55 & 45 & 35 & 30 & 30 & 30 \\
\hline
\end{tabular}

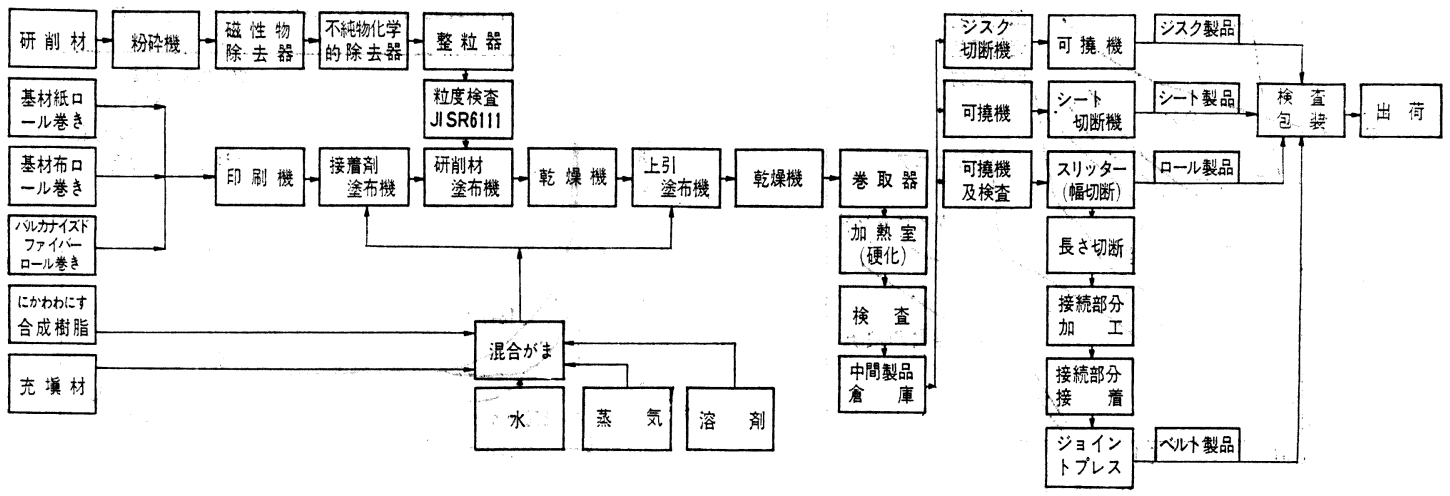


なお，非鉄金属，木材，皮革，塗料塗装面用研磨布紙 は研粒塗布面積の 50〜70\% に䂠粒を塗布したオープン コートもある.

基材, 接着剤と充填材, 砥粒の重量割合を表-3 に示 †.

表-3

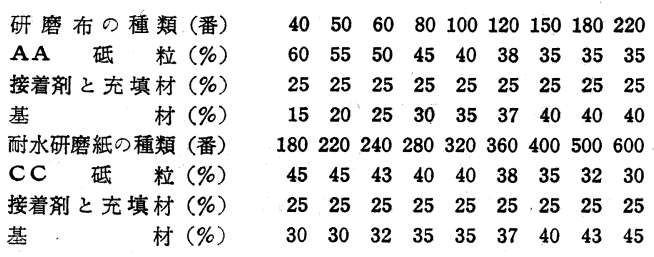

(4) 性 質

研磨布紙研磨工具の研削研磨特性，能率，寿命など機 械加工に関する文献 ${ }^{10)}$ は沢山ある。

研削研磨力は砥粒の切削縁の形状，接着剤層内外の無 秩序な䃌粒の配置に関係し, 研磨条件 (研磨状態, 研磨 布紙の張力, 冷却条件など）によって変る, 図 $-2,3$ は

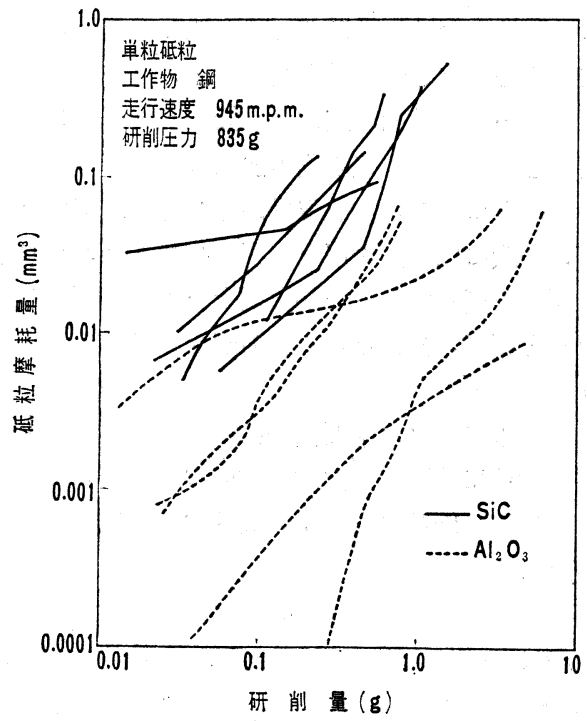

図-2 $\mathrm{SiC}$ と $\mathrm{Al}_{2} \mathrm{O}_{3}$ の研削量と磨耗量の比較(

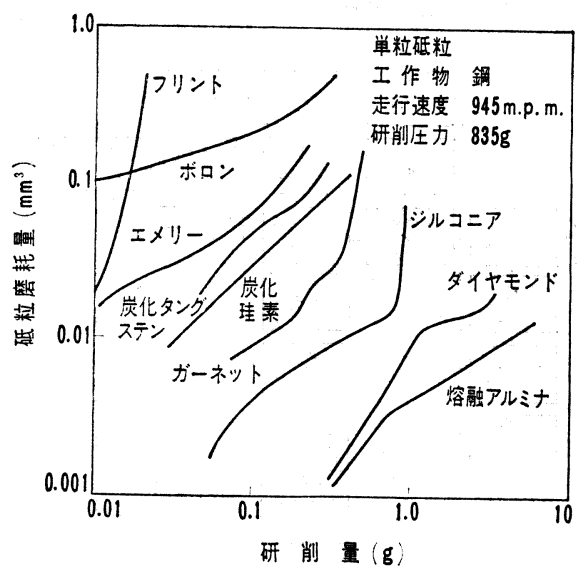

図-3 各種砥粒の研削量と磨耗量の比較()
砥粒磨耗量之研削量の 関係を示し, 図-4 は熔融アル ナと炭化珪素の研削率を比較し，図-5～6 は工具の走 速度と研削率の関係を示し，図-7 はコンタクトホイ。 ルの硬度と研削率の関係 ${ }^{11}$ を示し, 図-8 は研磨圧力 研磨量の関係を示す ${ }^{12)}$ ．砥粒サイズと研磨量の関係は1 -9〜11 および表-4 に示す.

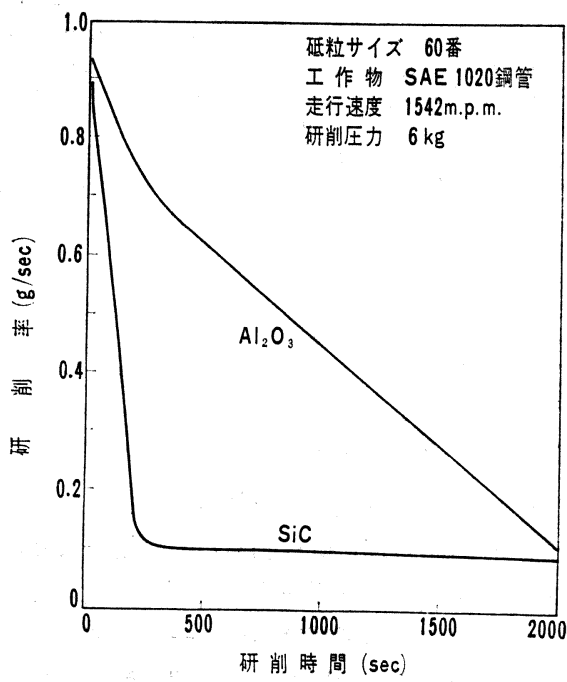

図-4 研磨布紙加工における熔融フルミナと 炭化珪素の研削率》

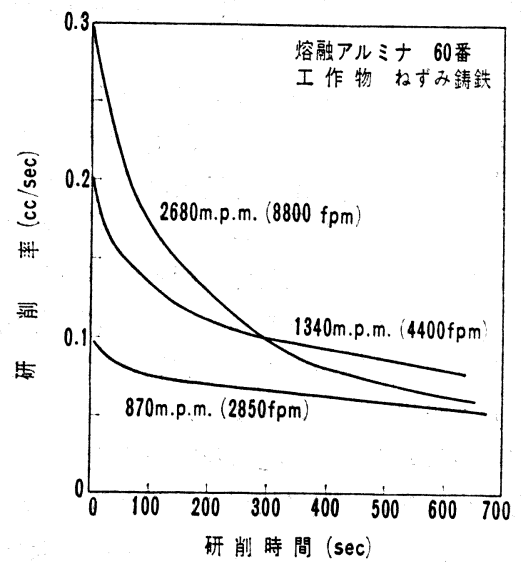

図-5 研磨布紙走行速度が研削率に及ぼす影響 11 )

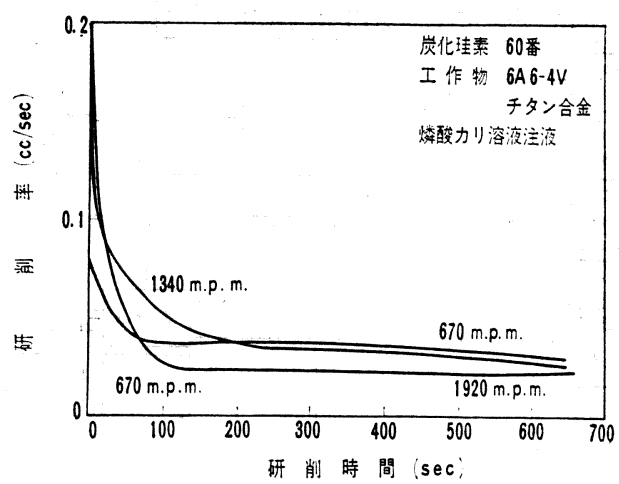

図-6 研摩布紙走行速度が研削率に及ず影響 ${ }^{11)}$ 


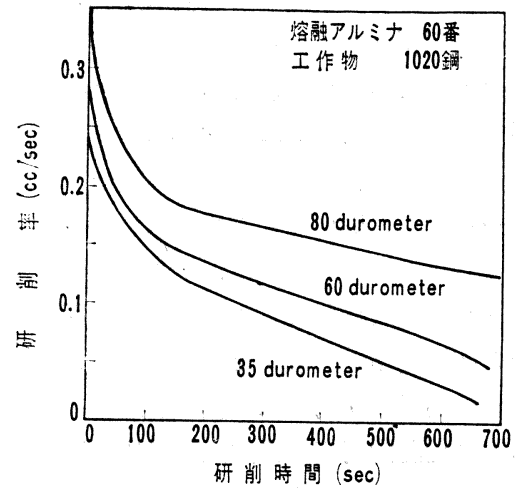

図-7 コンタクトホイールの硬度が研削率に及ぼす影響 ${ }^{11)}$

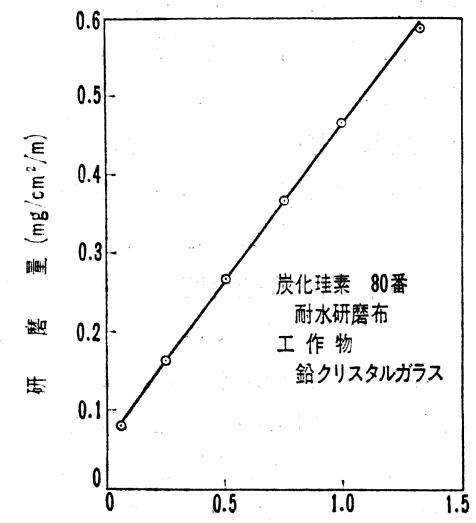

研磨压力 $\left(\mathrm{kg} / \mathrm{cm}^{2}\right)$

図-8，研磨圧力と研磨量の関係 ${ }^{12}$

表-4

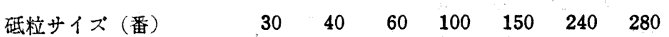
$\begin{array}{llllllll}\text { 研磨量 ( } \mathrm{g} \text { ) } & 6.59 & -8.46 & 6.01 & 5.21 & 2.19 & 1.47 & 0.77\end{array}$

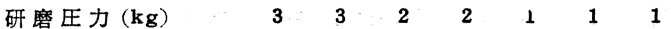
走行速度 (m.p.m.) $\quad 500 \quad 500 \quad 500 \quad 500 \quad 350 \quad 350 \quad 350$ 研磨布, 熔融アルミナ $\mathrm{AA}$ ：工作物軟鋼, 研磨時間 5 分間

機械加工工具として 種々なる 使用法 ${ }^{14)}$ があるが，一 般的には冷却剤を使用すると一定研磨圧力で砥粒の磨耗 率をへらし切削研磨能率を高めることができる. 湿式法 による一般的研磨条件を表一 $5^{15)}$ に示す.

研磨布紙工具の機械加工は時間的に 3 段階に分けて考 えられる，1）不確実に固着している砥粒および配向不 良砥粒の破壊之脱落, 一部の硅粒は他の研粒より著しく 遅れて切削を始め, 他の一部の砥粒は切削に全く関与し ない，また研磨布紙面と工作物面の間に遊離砥粒が発生 し，それらが両者の間を転がりながら自動研削研磨現象磨布紙は砥粒固 着が強固なために第 3 段階の発生は少な を起とす. 2) 砥粒の摩擦消耗と 効果的切削研磨と研磨に伴う工作 物微粉の硑粒間空げきへの充填 (目づまり) による能率低下が起 こる.3）研磨布紙が弾力性を失 ないシワが発生するため, 残存固 着碰粒の集中的脱落と研磨布紙の 㧧度低下が起こる. 一般的に二カ

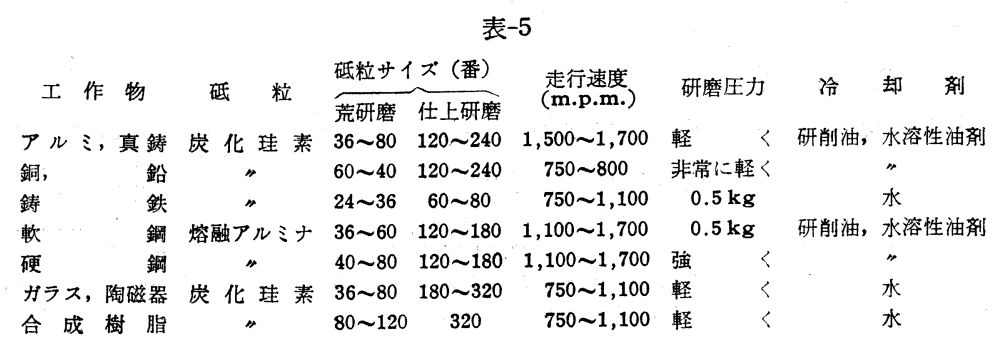


W.

碰粒磨耗は切削能率を低下するが，砥粒の破砕は新し い切削刃を形成するので研削性能を高める，炭化珪素よ り熔融アルミナ砥粒は磨耗が小さいが, 研磨布紙では熔 融アルミナの方が砥粒消耗が多いのは砥粒の破砕による のであろう。

\section{文献}

1）研磨布紙協会発表（38 年 5 10 月）

2）金子 靖. 塗料工業, 37 年 11 月号 24-27 頁

3）山口悟郎. 窯協研究発表講演会, 昭和 37 年 4 月, 特許 昭 38-20798

4）岩井津一, 鯉江七郎. 未発表

5）船橋 渡. 研磨布紙協会研究発表講演会, 昭和 38 年 11 月

6) E.J. Duwell \& W.J. McDonald. Wear 4, 372-383, 1961

7）日本工業規格. JIS R-6251 6255

8) L.J.H. Slack \& J.P. Dewar. Metal Finishing Jour., 8, [93], 313-315, 1962.; Anon. Grinding \& Finishing 9 [7] 33-36, 9 [8] 36-38, 1963

9) R.S. Bingham Jr., Ind. Qualiy Control, 19 [5] 512 Nov., 1962

10) 精密機械, 24 [11], 609-655, 昭 33

11) J.M. Pitblado. Tool Engr., 41, [10] 113-116 1958

12) 年遠藤幸雄. 化学関係学協会連合研究発表会 (1960-10)

13）：研磨布紙協会. 研磨布紙研磨力試験方法に 関する研究, 昭 $35-9$

14) Coated Abrasives- Mordern Tool of Industry, McGrw-Hill Book Comp. 1958

15) J.A. Simmons. Sundstrand Corp., Tech. Rep., 1962 (三共理化学研究所 鯉江 七郎)

\section{3 レジノイド砥石}

研削砥石は結合剤の種類によってレジノイド（合成樹 脂質）砥石，ビトリファイド（磁器質）砥石その他ラバ 一 (ゴム質)，シェラック (天然樹脂質)，シリケート (水ガラス質)，オキシクロライド質，メタル（金属質） などの砥石がある。

レジノイド砥石はビトリファイド砥石に比べ焼成温度 が $150^{\circ} \sim 200^{\circ} \mathrm{C}$ ではるかに低く, 加熱, 冷却に要する時 間が短かく焼成による砥粒本質の変化が全然なく，設備 が比較的簡単で, 砥石の機械的強度が大で使用時の走行 速度が高くでき，研削摩擦熱で結合剤が適宜然焼し去り 新しい砥粒切刃が現われ目づまりなく砥石の消耗が少な く, 弾性に富み耐衝撃性が大で使用中の安全度が高く研 削能率が大きい。

近年用途範囲が拡大しつつあり，研削砥石生産高でレ ジノイド砥石のしめる割合は表-1 ${ }^{1)}$ のようで 37 年度は 33 年度の 11 倍になった。

(1) 原 材 料

（1-1）砥粒. 熔融アルミナ (A, WA), 炭化珪素

表-1 研削砥石製法別生産割合 ${ }^{1)}$

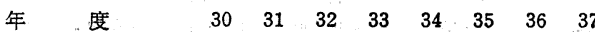

レジノイト研石 (\%) $2.9 \quad 6.010 .7 \quad 16.523 .427 .530 .534 .1$

ビトリファイド砥石 (\%) 92.888 .883 .076 .570 .465 .857 .353 .3

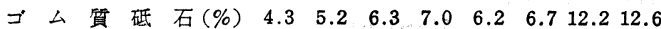

(C, GC), ダイヤモンドなどの䃌粒が用いられる。熔融 アルミナの新品質ノルトン社 $75 \mathrm{~A}$ やカーボランダム社 PA などが碰石に実用化されている．勒性の非常に高い National Lead 社のジルコニアチタニア系碰粒 (TAM 85/15) ${ }^{2)}$ や砥粒表面にビニルポリシロキサンやセラミッ クス材料を被覆した砥粒なども使用されている。

（1-2）結合剤 フェノールとホルマリンより作られ たフェノール系合成樹脂でアルカリ触媒で反応させたレ ゾール型の液状樹脂と酸触媒で反応させたノボラック型 の粉末樹脂の両者が使用され，粉末樹脂が主体である. 液状樹脂は砥粒湿潤用で品質向上の目的で碰石製造者が 自家生産しているとてろもあるが，一般には樹脂生産会 社より供給されている．ビトリファイド碰石結合剤のよ うに天然産不定性でなく，一定品質のものが容易に得ら れるが高価である.フェノール系樹脂の融点, 軟化点, 流動性, 結合強度, 耐熱度, 耐老化性, 価格などは樹脂 生産会社により差違がある.ラバーフェノール系，ポリ エステル系，エポキシ系樹脂なども使用されている。

（1-3）充填剤 樹脂の結合度向上や砥石の研削性能 向上にアルミナ, 弁柄, アルミニウム, パイライト, 炭 酸塩類, 硫酸塩類, 弗化硼素酸塩, 珪藻土, 氷晶石など が充填剤として用いられている．粒子の大きさと添加量 によって結合度や研削性能が影響を受ける。

（1-4）補強材 砋石の屈曲, 衝撃, 破裂などの機械 的強度を向上させるため麻布，合成センイ布，ガラス 布，鋼網などが補強基材として使用されている。

\section{（2）製 造 法}

䃌粒と液状樹脂を混合機で混合し，䃌粒表面を均一に 湿潤させたのち粉末樹脂を少量ずつ添加して砥粒面を均 一に樹脂皮膜で被覆する。

砥粒と樹脂の割合は，砥粒サイズ（粒子個数とその総 表面積）と樹脂によって異なるが，一般に䃌粒重量の 10〜25\% の樹脂が用いられ，それらに関連するデータ

表-2 熔融アルミナ砥粒 $1 \mathrm{~kg}$ の表面積と砥粒個数比

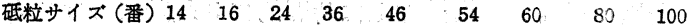

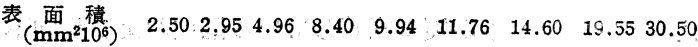
個数，比 $1.001 .667 .7738 .0864 .85 .106 .00182 .00508 .5 \quad 1,457$

表-3 熔融アルミナおよび炭化珪素砥粒の等価体積径(

\begin{tabular}{|c|c|c|c|c|c|c|c|}
\hline Fut & & 24 & 36 & 46 & 60 & 80 & 120 \\
\hline \multirow{2}{*}{$\begin{array}{c}\text { 硅粒 } 1 \text { 個重量 } \\
\text { (mg) }\end{array}$} & & 1.089 & 0.338 & 0.104 & 0.028 & 0.016 & 0.0 \\
\hline & & 0. & 0.250 & 0.078 & 0.029 & 0.007 & \\
\hline \multirow{2}{*}{$\begin{array}{c}\text { 等価体皘径 } \\
(\mathrm{mm})\end{array}$} & $r_{A}$ & 0.81 & 0.55 & 0.37 & 0.24 & 0.20 & \\
\hline & & & 0.5 & 0.3 & 0.26 & 0.16 & \\
\hline
\end{tabular}

表-4 熔融了ルミナ砥粒と樹脂配合例 ${ }^{3}$ )

$$
\text { A B C } \text { D E F }
$$

研粒サイズ.24 番 $1000100 \quad 100$ 研粒サイズ 36 番 $100 \quad 100100$

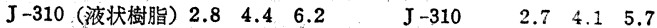

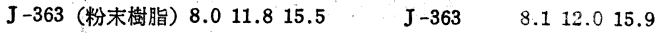
成形圧力 $100 \mathrm{~kg} / \mathrm{cm}^{2}$ (常温), 成形品密度 $2.36 \mathrm{~g} / \mathrm{cm}^{3}$, 枆石厚さ $10 \mathrm{~mm}$ 以下焼成条件

常温 $\rightarrow 80^{\circ} \mathrm{C} 1$ 時間, $80^{\circ} \mathrm{C}$ 保持 2 時間, $80^{\circ} \rightarrow 180^{\circ} \mathrm{C} 10$ 時間， $180^{\circ} \mathrm{C}$. 保持 2 . 時間以後徐冷 
を表-2 4 亿示す.

フニノール系樹脂には未反応フェノール, メチロール 基, 吸湿性触媒などが含まれていて吸湿すれば結合力が 低下するから特に注意を必要とし湿度, 温度を調節した 室内で混合と成形を行なう．成形はコールドフレスで最 近はホットプレスの使用が盛んになった．加圧はほとん ぞが両面圧締方式である. 形圧成 $50 \sim 250 \mathrm{~kg} / \mathrm{cm}^{2}$ で低 石の種類によって違い加圧時間は製品の厚さによって決 まる. 補強基材の埋設は別の成形器で行なう. 焼成は䃌 石製造上, 最重要作業で温度上昇速度が重要, 焼成温度 と時間は樹脂メーカーが指定しているものが多い，焼成 後は徐冷する.

\section{(3) 性 質}

$1 \mathrm{~m}$ 以上の大形ロール研磨䃌石からマッチ軸の頭ほど の砥石, ペン先を割る約 $0.1 \mathrm{~mm}$ の極薄砈石など種々あ り，日本工業規格は一般研削碰石，オフセット研削碰 石, 切断研石 (JIS R 6212 4) があり研削砥石の選択 標準 (JIS B 4051) が決められている.レジノイド砥石 とビトリファイド低石の研削量, 消耗量の比較を表 $-5^{6)}$ およで図-1 ${ }^{7)}$ 亿示し，表-6 亿前述（表-4）で作ったも のの結合度 (JIS R 6212) と引張り強さを示し, 各種切 断低石の物理的性質は表-7 $\left.7^{8}\right)$ に示した。

\begin{tabular}{|c|c|c|c|c|}
\hline & 研削量 & $\begin{array}{l}\text { 碈石 } \\
\text { 消耗量 }\end{array}$ & 研削比 & 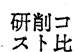 \\
\hline シノイト础石 & 1.220 & 0.0725 & 16.8 & 1.00 \\
\hline $\begin{array}{l}\text { ピトリファイド砥石 } \\
\text { エ作物……可錣鋳鉄材 }\end{array}$ & 0.920 & 0.109 & 8.4 & 1.17 \\
\hline
\end{tabular}

表-6 結合度と引張り強さ ${ }^{5)}$

\begin{tabular}{|c|c|c|c|c|c|c|}
\hline & A & B & $\mathrm{C}$ & $\mathrm{D}$ & $\mathrm{E}$ & F \\
\hline 結 合 度 $(\mathrm{mm})$ & 0.54 & 0.38 & 0.35 & 0.47 & 0.37 & 0.31 \\
\hline 引張り強さ $\left(\mathrm{kg} / \mathrm{cm}^{2}\right)$ & 114 & 142 & 153 & 139 & 157 & 172 \\
\hline
\end{tabular}
表-7 切断低石の物理的性質象

\begin{tabular}{|c|c|c|c|}
\hline 础石 强度 & $\begin{array}{l}\text { 破裂速度 } \\
\text { (m.p.m) }\end{array}$ & 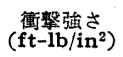 & $\begin{array}{c}\text { 屈曲強さ } \\
(\mathrm{psi})\end{array}$ \\
\hline 補強基材なし & 6,100 & 75 & 1,000 \\
\hline 層 & 8,230 & 125 & 2,000 \\
\hline ガラス布（半剛） & 9,150 & 300 & 5,000 \\
\hline " (強用) & 12,200 & 400 & 7,000 \\
\hline
\end{tabular}

工作物之研削材の種類との関係は従来より鋳鉄には炭 化珠素，鋼には熔融アルミナといわれているが，研削材 への工作物材料の熔着および化学反応より理論的根拠と なるであろう結果を表-8 亿示した。

単粒による研削作用，砥石表面の構造と仕上面あらさ 研石減耗および切刃の自生作用, 研削抵抗および研削温 表-8 研削材に及ぼす工作物材料の関倸 ${ }^{2}$

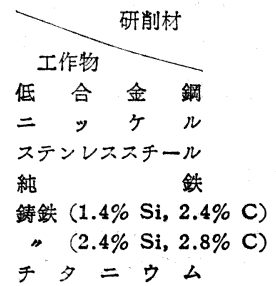

\begin{tabular}{|c|c|c|c|c|c|}
\hline \multicolumn{3}{|c|}{ 熔融アルミナ } & \multicolumn{2}{|c|}{ 炭 化 珪 } & \\
\hline & 熔着 & 磨耗 & 反応 & 熔着 & \\
\hline & な & & & & \\
\hline & な & & & $\infty$ & \\
\hline & なし & 中 & 1 & क? & \\
\hline & 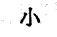 & & & & \\
\hline & 小 & 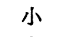 & + & なし & \\
\hline & 小 & 小 & 特小 & なし & \\
\hline & & & & & \\
\hline
\end{tabular}

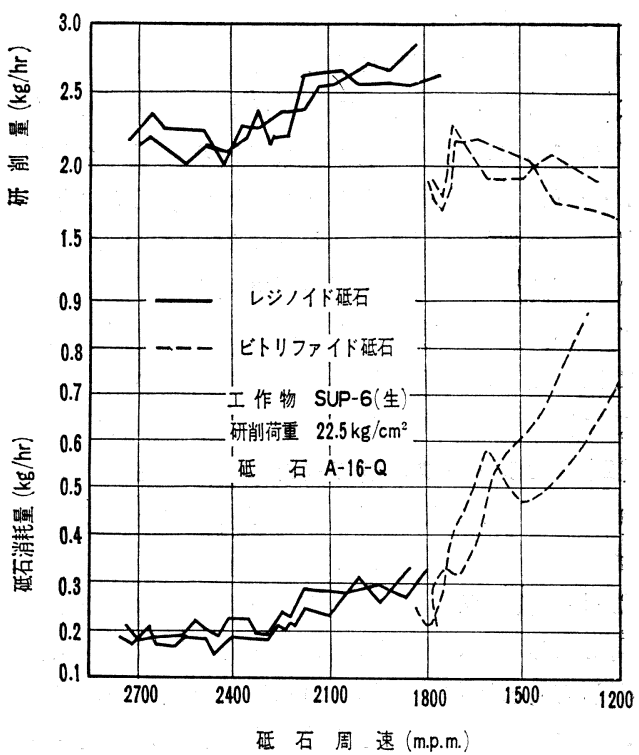

四-1 レジノイド砥石とビトリファイド砥石の比較 度, 研削液の作用など研削理論に関する研究について最 近のものをまこめた報告 ${ }^{10)}$ がある.

\section{文…献}

1) 研削砥石工業会発表による.

2) C.W.F. Jacobs, Grinding \& Finishing, 5; [9], 4142,1959

3) N.P. Robie, Grinding \& Finishing, 7, [12], 44-46, 1961

4). 笹谷重康.機械と工具, [9] 25-30, 1960

5）大日本インキ化学工業 (株).レポート Ply 27 , July, 1962

6）名古屋エラスチック製砥 (株).カタログ

7) . 岡井 弘. 窯協, 69 [12], 36-45, 1961.

8) P.L. Shanta, Modern Plastics, 140, 146-149, Sept., 1955

9) G.J. Goepfert \& J.L. Williams Mech. Engg., 81 [4], 69-73, 1959

10）竹中規雄, 機械学会誌, 66 [528], 85-89, 1963

\section{(三共理化学研究所 鯉江 七郎)}

\section{4 パイト, ツール}

\section{(1) 概 要}

超硬合金が始めて市場に出た 1926 年から約 10 年お くれて，1938 年にセラミックスが切削工具として武用 された．当時はドイッで非鉄金属を切削しただけにとど まったが，その頃からセラミックスを切削工具として実 用に供しようとする気運がたかまり，1950 年代に入。 てソ連，イギリス，ドイッ，などで本格的にセラミック 切削工具に上る金属切削を対象 とした研究が進められ た。

わが国においても 1958 年 5 月東京国際見本市で，国 産品が欧米各国のセラミック切削工具のもつ切削性能を 凌駕する品種を発表した．最近ではわが国で 4 社，欧州 で約 20 社, 米国で約 10 社がセラミック切削工具の製 
造に着手している。

切削工具として使われるセラミックスはアルミナ系セ ラミックスで切削の分野では，それが化学的に高温で， 安定していて, 耐磨耗性が優れていることに着目され た・一方アルミナ系セラミックスは化学工業などで耐薬 品性と耐磨耗性の両者を必要とする部分に，バルブ，， ズル，ダイスそして型などの耐磨耗工具として広く用い られているが，アルミナ系セラミックスは耐磨耗工具と しては，まだ切削工具程広く使用されていないので，乙 こでは特に切削工具としてのセラミックスを照介する.

\section{（2）セラミック切削工具としての特性}

セラミックスを切削工具として用いたときの長所と短 所は次のような諸点である。

（2-1）長 所 1） セラミックス自体が安定した酸 化物であるので, 高温高圧の生ずるような切削条件下で 切削しても被削材と工具との間に化学反応を起こしにく い.また被削材に対して溶着温度が高い.したがって超 硬合金や高速度鋼製の切削工具に見られるような工具の 掬い面に発生するクレーター損傷は起こりにくく，これ によって, 工具寿命が左右される心配は少ない。

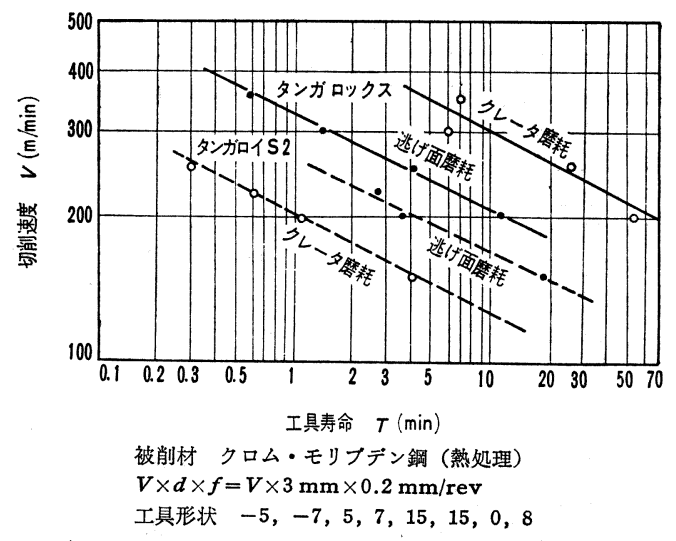

図-1 タンガロックス（セラミックス）と超硬合金 (タンガロイ）の工具寿命比較

図 1 は炭素鋼をセラミックの切削工具と超硬切削工具 で切削した時の V-T 線図である. この図は個々の工具 材種でクレーター磨耗曲線と逃げ面磨耗曲線の相対位置 が逆になっている.

2) セラミックスは高温での硬度, 抗折力值, 強度な どの低下する割合が他の切削工具材種に比較して少な く, したがって高速切削に耐えられ, 切削作業の高能率 化および切削時の経済性が増加する.

3）七ラミックスは非電導性であるので, 電気化学的 磨耗すなわちエロージョンを起ししにくい.

（2-2）短所 1） セラミック切削工具は超硬切削工 具亡比較して，金属的なバインダーが全く使用されてい ないか，あるいはごく少量添加されているために鞄性に 乏しい：したがって衝撃や振動を伴う切削作業には弱い ので不向きであり，切削使用条件が割合に狭い。
2）熱伝導率や熱膨脹率が他の切削工具材種と相当差 異があるために工具形式が限られてしまう，表-1 にセ ラミックスの特性表を示す.

表-1 セラミックスと超硬合金材種の物理的, 機械的性質

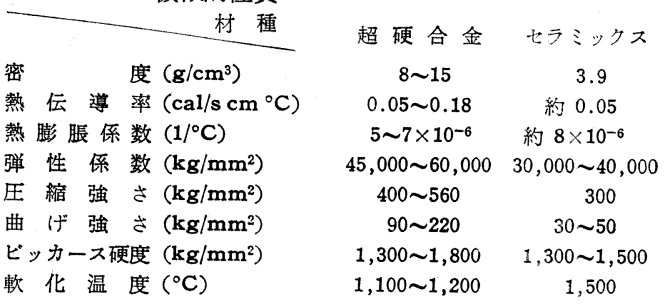

\section{(3) 切削工具としてのセラミックスの材種}

セラミックスの切削工具材種には次の 3 種類があり, それぞれアルミナのもつ長所を生かして, 短所をカバー するととを考えて作られている。

1）アルミナ，セラミックス：純粋のアルミニウムオ キサイドを主体とした材種

2) アルミナーメタル系セラミックス：アルミニウム オキサイドと金属との混合物

3）アルミナーカーバイド系セラミックス：アルミニ ウムオキサイドとメタルカーバイドの混合物

アルミナーメタル系セラミックスとアルミナーカーバイ ド系セラミックスはそれぞれ金属および金属炭化物をバ インダーにして，七ラミックス特有の脆さを除いてあ る・したがって耐磨耗性や耐熱性はアルミナセラミック ス系材種には及ばないが, 衝撃や断続を伴う切削や取り 扱い易さ，すなわち切削作業以外の鈴付性や研削性は優 れている.いい換えると金属性物質をバインダーにした これらのセラミックスは超硬合金と比較して特性だけで なく，切削性能も類似している.

いろいろの特性を考えて，アルミナセラミックス系材 種は切削速度の高いところで使用し，アルミナーカーバ イド系材種は切削速度が割合に低いところで使うとよい 結果が得られる。

（4）セラミックスの粒の大きさと切削性能の関係 セラミックスの切削性能は, その材種の成分や密度に よることは勿論, 粒の大きさにも非常に関係している.

図-2 は最近あるる外国のメーカーの製造したセラミッ クスにおけるアルミナの粒の大きさと切削性能の関係を 示したものである. 粒の大きさは, 1956 年頃 $10 \mu$ 程度 であって超硬切削工具よりも切削性能は悪かったが, 最 近では粒の大きさが $5 \mu$ 以下になり，CK $45 \mathrm{~N}$ (ドィッ 規格品）を削ったときの逃げ面磨耗带幅も従来の $1 / 3$ 以 下になっている.すなわち粒が細かいほど逃げ面磨耗量 が少なくなっている。

\section{（5）セラミック切削工具の損傷}

セラミック切削工具の使用条件は切削条件にしても, 工具形状にしても十分セラミックスの特性を考えて決め 
波削材 CK45N V XdXf Xt $200 \mathrm{~m} / \mathrm{min} \times 1.5 \mathrm{~mm} \times 0.315 \mathrm{~mm} / \mathrm{rev} \times 60 \mathrm{~min}$

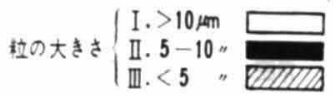

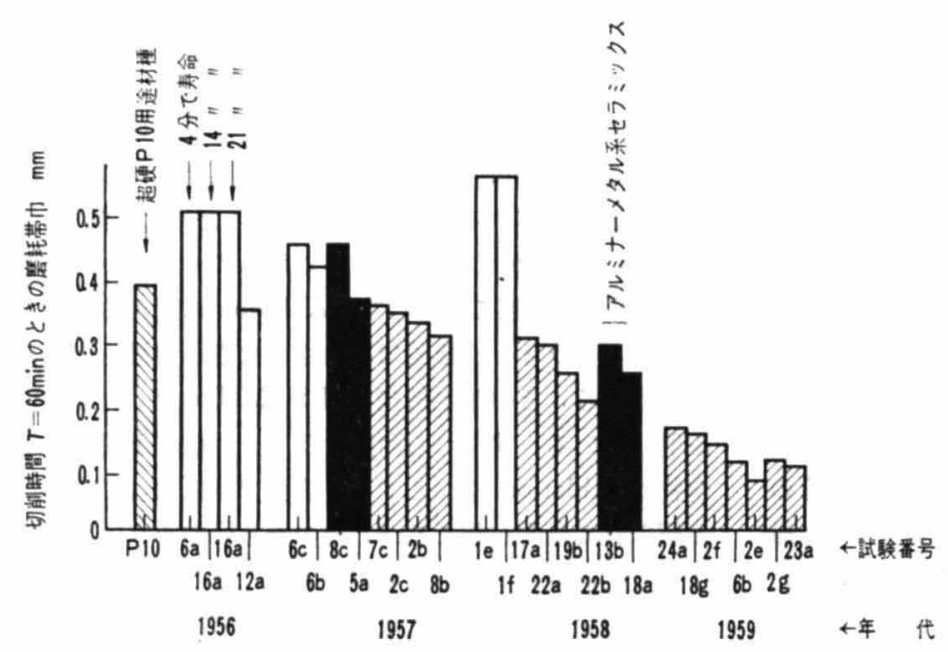

図-2 アルミナ粒の大きさと磨耗量の関係

な損笏を与えるようなことは少ない，ま たこ机らの刍裂とは別にくり返し衙撃に よって切刃の圧縮応力を得て起てる横英 裂が生ずるとともある. この色裂は特に 切刃付近に起きない限り徐々にその大き さを增すが，切刃付近に起こったり，熱 色裂と基盤状に交叉すると切刃の欠損が 起こりやすく工具寿命を短かくする・上 記の観察は主として $\times 30 〜 \times 100$ 倍の工 具䫓薇鏡やルーペによって行なえるか， 同一損傷を電子顥微鏡によって観察して 見るとクレータ損傷部や逃げ面磨耗部に 被削材が展延されて損笏部上面を薄く覆 っている.図-7 はクレータ部の損笏を 電子顕微鏡で観察したもので, 薄膜で覆 われた磨耗面を示している。この現象は 超硬切削工具の損傷と同じように溶着か 起とりこの溶着は被削材の炭素含有量が 少なけ机ば，少ないほど著しい傾向があ

ければならないか，いくら注意しても切刃の損陽はさけ がたい. 切削時に起こるこの種の工具損傷について巨 視的に見ると，その損傷は概ね超硬切削工具などの損第 似類していると見なして良い，すなわち逃げ面宕耗と クレーター磨耗, そしてチッピングが代表的な損侮であ る.

なお,このほかにセラミックスの熱に対する特性のた めに逃げ面や掬い面に切刃にほぼ直角に何本かの熱龟裂 が起こり易く, これらの龟裂は切威中切首の擦過によ。 て, ある程度幅が拡げられるか, それらは切刃に致命的
る.しかしこの薄膜を何らかの方法で取り除くとアルミ ナの粒が露出し, 図-3のように粒の角が少しう゚つ崩壊し 粒表面には切首による擦過痕を明瞭に残している. 図 -3 と図-4 は同一部を示したものである. 七ラミックス がある原因で欠損したり，大きくチッピングした破面の 電子顕微鏡写真は粒子の結合強さにより異なり, 粒子面 の状態が雛の少ない平滑なものは雛の多い粒よりも一般 に強度的には低い場合が多い。

\section{（6）セラミック切削工具の将来}

最近では各国でセラミックスの鞀性か增してきたため

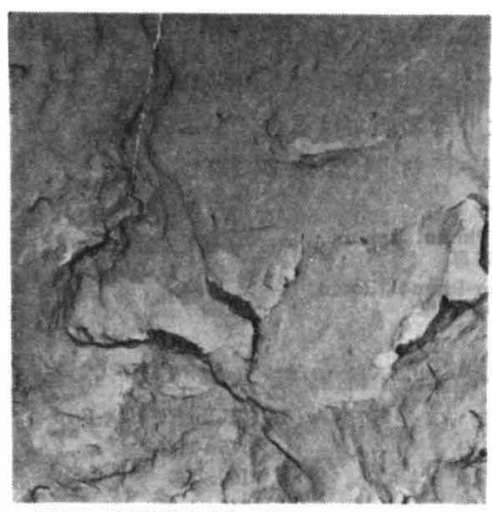

被能材 $\mathrm{SNCM} 8\left(\mathrm{Hs} 45^{\circ}\right)$

$\boldsymbol{V} \times \boldsymbol{d} \times f=310 \mathrm{~m} / \mathrm{min} \times 1.0 \mathrm{~mm} \times 2 \mathrm{~mm} / \mathrm{rev}$

TA-31-4 ホルダー使用

表面末処理

培事 $\times 4,000$

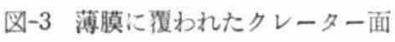

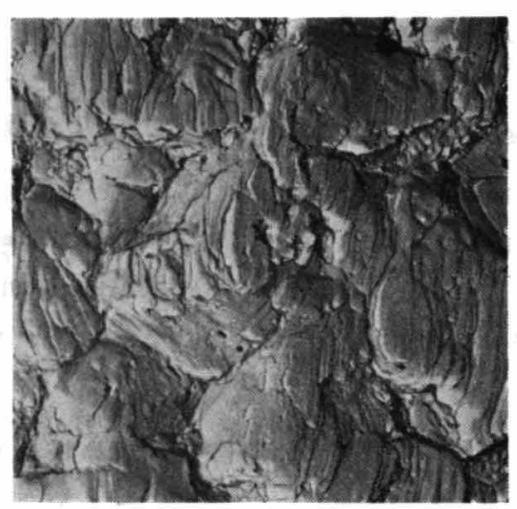

(アルミナ柆罣出)

策件同左

表面 $\mathrm{HCL}$ 処理

倍事 $\times 4,000$

図-4 薄膜を取去ったクレーター面
に, セラミックスカッター類を試 作し，遇撃を半う断続切削域にま で, この種の工具材種を利用しよ うとして，鋳鉄などの切削に好結 果を示している例がある. 時代が 進むにつれて高級な被削材を高能 率に切削するという要望から七う ミック切削工具材種としても前述 した,アルミナーカーパイド系セ ラミックスをも含めて，できるだ け䩓性のたかいセラミック切削工 具の改良に留意研究が進められて いる.

（東芝タンガロイ株式会社 木村 忠彦) 